\title{
Carbon Dioxide Storage in Natural Gas Reservoirs
}

\author{
B. van der Meer ${ }^{1}$ \\ 1 TNO Built Environment and Geosciences, Princetonlaan 6, 3508 TA Utrecht - The Netherlands \\ e-mail: Bert.vanderMeer@tno.nl
}

Résumé - Stockage de $\mathrm{CO}_{2}$ dans des réservoirs de gaz naturel - Le principe du stockage de $\mathrm{CO}_{2}$ dans des réservoirs de gaz naturel repose sur l'idée que le volume de gaz produit (gaz et condensat) est remplacé par le $\mathrm{CO}_{2}$. Cet article étudie la faisabilité du stockage de $\mathrm{CO}_{2}$ dans ce type de réservoirs, qui ont déjà fait leur preuve puisqu'ils piègent du gaz depuis des milliers voire des millions d'années. La capacité de stockage des réservoirs déplétés dépend de nombreux facteurs détaillés dans l'article.

\begin{abstract}
Carbon Dioxide Storage in Natural Gas Reservoir - The general idea of $\mathrm{CO}_{2}$ disposal in gas reservoirs is that the underground volume of the ultimately recoverable hydrocarbons (gas and condensate) is replaced by $\mathrm{CO}_{2}$. This paper investigates the feasibility of carbon dioxide disposal in depleted gas reservoirs. Gas reservoirs are a practical storage site for the carbon dioxide, because the presence of the hydrocarbons that were trapped in the subsurface for thousands to millions of years proves that they can retain the carbon dioxide safely. The storage capacity of depleted gas reservoirs depends on numerous factors reviewed in this paper.
\end{abstract}




\section{INTRODUCTION}

The attraction of disposing $\mathrm{CO}_{2}$ in exhausted hydrocarbon reservoirs is that underground withdrawal of fossil fuels can be balanced by $\mathrm{CO}_{2}$ storage in the subsurface. In other words, if the fuels are used (burned), they are simply disposed of in the reservoir they came from. However, a closer look at the combustion of fossil fuels shows that this may be too optimistic.

Fossil fuels contain carbon and hydrogen. When they are burned, carbon dioxide and water are produced. If instead of air, pure oxygen is used, the combustion of natural gas, oil and coal is as follows:

natural gas:

$\mathrm{CH}_{4}+2 \mathrm{O}_{2} \rightarrow \mathrm{CO}_{2}+2 \mathrm{H}_{2} \mathrm{O}$

fuel oil:

$2 \mathrm{CH}_{2}+3 \mathrm{O}_{2} \rightarrow 2 \mathrm{CO}_{2}+2 \mathrm{H}_{2} \mathrm{O}$

coal:

$\mathrm{C}+\mathrm{O}_{2} \rightarrow \mathrm{CO}_{2}$

The material balance by weight is:

natural gas:

$1 \mathrm{~kg} \mathrm{CH}_{4}+4 \mathrm{~kg} \mathrm{O}_{2} \rightarrow 2.75 \mathrm{~kg} \mathrm{CO}_{2}+2.25 \mathrm{~kg} \mathrm{H}_{2} \mathrm{O}$

fuel oil:

$1 \mathrm{~kg} \mathrm{CH}_{2}+3.43 \mathrm{~kg} \mathrm{O}_{2} \rightarrow 3.14 \mathrm{~kg} \mathrm{CO}_{2}+1.29 \mathrm{~kg} \mathrm{H}_{2} \mathrm{O}$

coal:

$1 \mathrm{~kg} \mathrm{C}+2.67 \mathrm{~kg} \mathrm{O}_{2} \rightarrow 3.67 \mathrm{~kg} \mathrm{CO}_{2}$

Assuming that the densities of natural gas, oil and $\mathrm{CO}_{2}$ under average reservoir conditions are 150, 800 and $700 \mathrm{~kg} / \mathrm{m}^{3}$ respectively, the material balance by underground volume for oil and gas is (ignoring oxygen and water):

natural gas:

$1 \mathrm{~m}^{3} \mathrm{CH}_{4} \rightarrow 0.59 \mathrm{~m}^{3} \mathrm{CO}_{2}$

fuel oil:

$1 \mathrm{~m}^{3} \mathrm{CH}_{2} \rightarrow 2.75 \mathrm{~m}^{3} 3 \mathrm{CO}_{2}$

So, it can be expected that the underground volume of the natural gas can be replaced by the $\mathrm{CO}_{2}$ produced by the burning of the gas. The burning of oil produces so much $\mathrm{CO}_{2}$ that the underground volume of oil is much smaller than the volume that would be occupied by the $\mathrm{CO}_{2}$ produced. Most power stations are, however, coal-based. The combustion of coal produces more $\mathrm{CO}_{2}$ that can be stored in the space the coal came from. If one wishes to dispose of the $\mathrm{CO}_{2}$ permanently, it has to be confined within depleted hydrocarbon reservoirs or a trap on an aquifer directly analogous to the hydrocarbon reservoir. The underground reservoir needs a sealed trap to prevent the $\mathrm{CO}_{2}$ from percolating upwards through the water and reaching the surface, because supercritical, 'liquid' $\mathrm{CO}_{2}$ is lighter than water and tends to force its way up through the water-saturated rocks. Hydrocarbon reservoirs have the following advantages over aquifers (JOULE II, 1993):

- exploration costs will be zero or limited,

- the reservoirs have a seal and a trap that have proved to be capable of retaining liquids or gases for thousands to millions of years,

- the reservoir properties, such as porosity, permeability, pressure, temperature and the overall storage capacity are well known,

- some of the equipment installed on the surface or underground for oil or gas recovery may be re-used for the carbon dioxide disposal.

\section{RESERVOIR CHARACTERISTICS}

Hydrocarbon reservoirs occur between the surface and a depth of about 6000 to $7000 \mathrm{~m}$. The average depth of 12018 oil reservoirs of any age and locality in the world is about $1500 \mathrm{~m}$, ca. $80 \%$ of these reservoirs are at a depth below $800 \mathrm{~m}$. Most of the hydrocarbon reserves are in Mesozoic (54\% oil and 44\% gas) and Cenozoic (32\% oil and $27 \%$ gas) basins (Tissot and Welte, 1984). About $15 \%$ of the depleted oil and gas reservoirs in the United States are at a depth of less than $900 \mathrm{~m}$ (Winter and Bergman, 1993). Reservoir rocks must be permeable and porous. The porosity usually ranges from 5\% to $30 \%$. A 'good' reservoir rock shows a permeability of more than $10 \mathrm{mD}$ and a porosity exceeding $15 \%$. Porosity normally decreases with depth, mainly due to recrystallization, pressure and cementation. More than $60 \%$ of the oil is found in sandstone or siltstone reservoirs, an additional $30 \%$ is in carbonates, and the remaining $10 \%$ in fractured shales, or igneous or metamorphic rocks. Practically all pores in the subsurface are watersaturated (Tissot and Welte, 1984).

Because gas is more mobile than oil and can migrate through smaller pores, gas reservoirs may show a lower permeability and may occur at shallower depths than oil reservoirs. The specific gravities of gas and oil, roughly between 5 and $320 \mathrm{~kg} / \mathrm{m}^{3}$ and between 700 and $900 \mathrm{~kg} / \mathrm{m}^{3}$ respectively, are considerably lower than that of the saline pore water, which has an average density of ca. $1100 \mathrm{~kg} / \mathrm{m}^{3}$. The hydrocarbons therefore tend to migrate upwards to the surface. In order to prevent them from escaping, the reservoir needs to be overlain by an impermeable layer (a seal) and be confined within a closed structure (a trap). Seals are normally layers of clay, shales, evaporites or other impervious rock. Anticlinal structures are the most common traps. Additional traps are formed by faults, salt domes, unconformities, reefs, or stratigraphic features. (JOULE II, 1993; Tissot and Welte, 1984; Katz et al., 1959).

Pressure and temperature increase with depth. Assuming an average geothermal gradient of $30^{\circ} \mathrm{C} / \mathrm{km}$ and a normal 


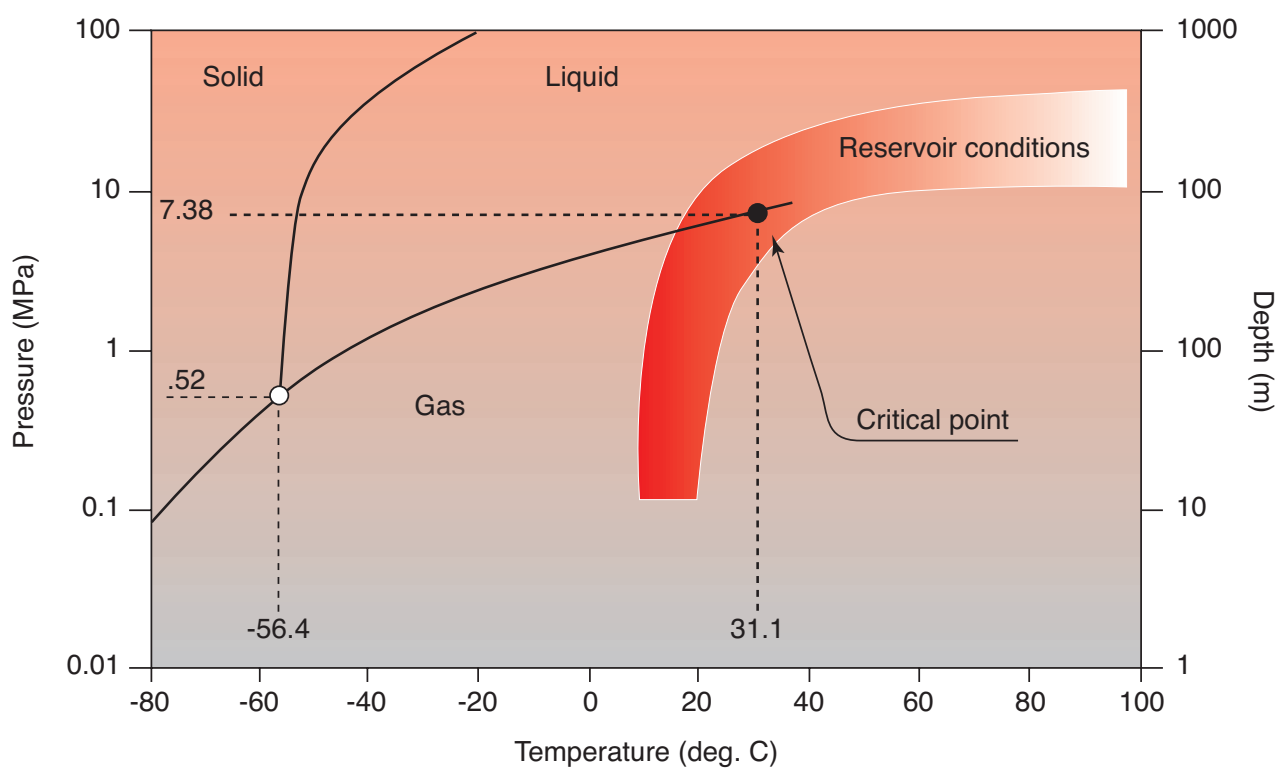

Figure 1

Phase behaviour of $\mathrm{CO}_{2}$.

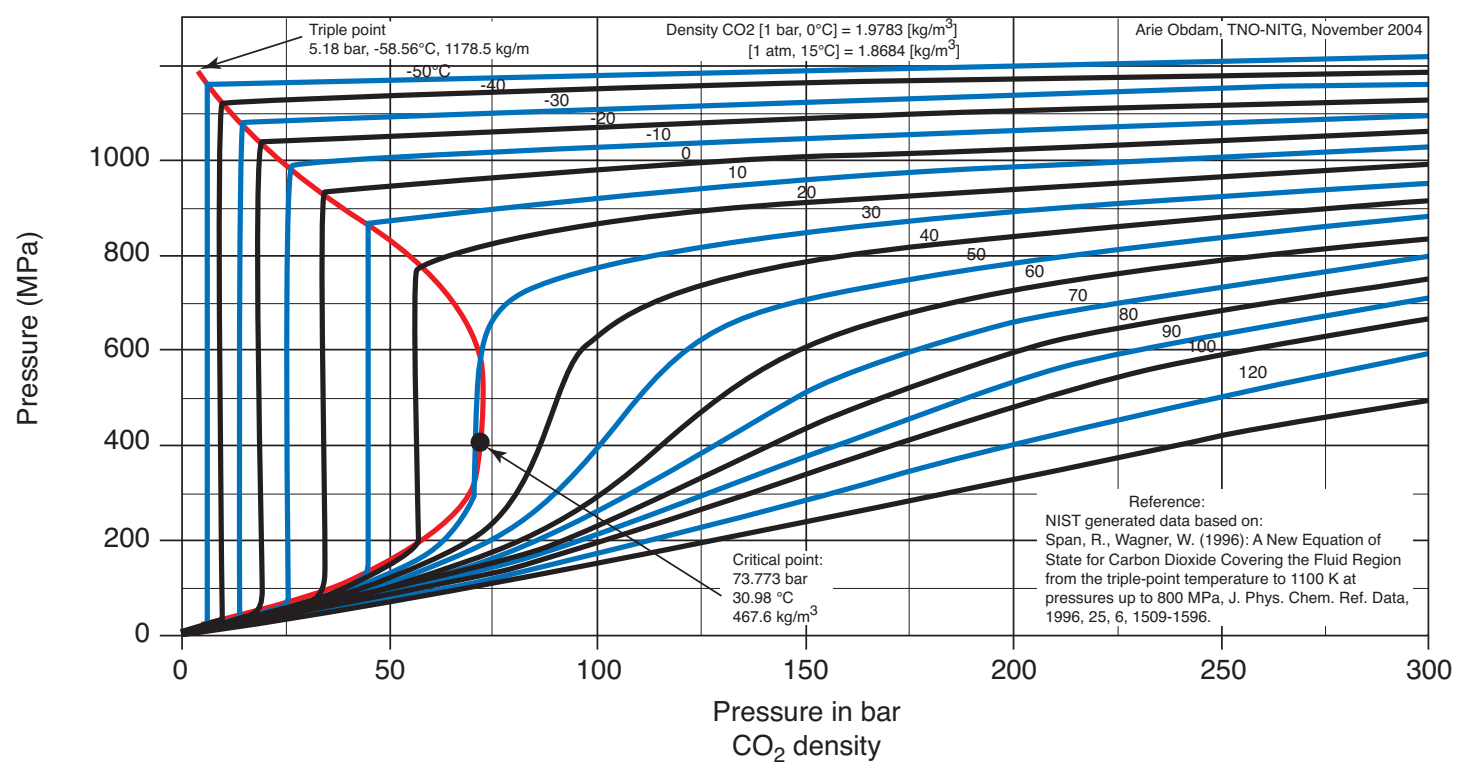

Figure 2

$\mathrm{CO}_{2}$ density as function of pressure and temperature.

hydrostatic gradient of ca. $10 \mathrm{MPa} / \mathrm{km}$, the temperature and pressure in a reservoir may reach $175^{\circ} \mathrm{C}$ and $70 \mathrm{MPa}$, respectively. The highest temperature recorded in wells, however, is ca. $280^{\circ} \mathrm{C}$ at a depth of $7800 \mathrm{~m}$, and maximum pressures are around $140 \mathrm{MPa}$. There is also a general increase of the pore water salinity with depth. The salinity gradients vary between 0.07 and $0.25 \mathrm{~g} / \mathrm{l} \mathrm{m}$, although in many cases the salinity is not linearly related to depth. Pore water salinities range from fresh water to brines with concentrations close to $300 \mathrm{~g} / \mathrm{l}$. Since salt water is heavier that fresh water, the hydrostatic gradient is normally more than $10 \mathrm{MPa} / \mathrm{km}$ (Tissot and Welte, 1984). 


\section{$2 \mathrm{CO}_{2}$ BEHAVIOUR UNDER RESERVOIR CONDITIONS}

The critical temperature of $\mathrm{CO}_{2}$ is $31.1^{\circ} \mathrm{C}$ and its critical pressure is $7.38 \mathrm{MPa}$ (Fig. 1). The underground temperature and pressure below a depth of about $800-850 \mathrm{~m}$ are such that $\mathrm{CO}_{2}$ is in its supercritical state, which means that no distinction can be made between liquid or vapour and that the $\mathrm{CO}_{2}$ acts as a gas-like compressible fluid that takes the shape of its container and fills it, but has a liquid-like density. Above this depth the $\mathrm{CO}_{2}$ is a gas and its density is too low to store large volumes economically (van der Meer et al., 1992; Holloway and Savage, 1993).

Supercritical $\mathrm{CO}_{2}$ is non-polar and a very good solvent for organic compounds. Its density and viscosity are a function of temperature and pressure (Figs 2, 3). At the underground temperature and pressure of interest, density varies between ca. $600 \mathrm{~kg} / \mathrm{m}^{3}\left(30^{\circ} \mathrm{C}, 8 \mathrm{Mpa}\right)$ and $800 \mathrm{~kg} / \mathrm{m}^{3}\left(160^{\circ} \mathrm{C}\right.$, $70 \mathrm{MPa})$ and the viscosity between ca. $0.04 \mathrm{cP}\left(30^{\circ} \mathrm{C}\right.$, $8 \mathrm{Mpa})$ and $0.08 \mathrm{cP}\left(160^{\circ} \mathrm{C}, 70 \mathrm{MPa}\right)$. By comparison, fresh water shows a density decreasing from $1000 \mathrm{~kg} / \mathrm{m}^{3}$ at surface conditions to about $920 \mathrm{~kg} / \mathrm{m}^{3}$ at a depth of $7000 \mathrm{~m}$, and its viscosity declines from 1.0 to $0.2 \mathrm{cP}$. Salt water, however, has a considerably greater density and viscosity (van der Meer et al., 1992; Kennedy and Thodes, 1961; Earlougher, 1977; Holloway and Savage, 1993).

The density of supercritical $\mathrm{CO}_{2}$ is significantly reduced if the $\mathrm{CO}_{2}$ is contaminated with methane $\left(\mathrm{CH}_{4}\right)$ : at a pressure of $19.3 \mathrm{MPa}$ and a temperature of $60^{\circ} \mathrm{C}$ density declines from ca. $700 \mathrm{~kg} / \mathrm{m}^{3}$ for pure $\mathrm{CO}_{2}$ to ca. $500 \mathrm{~kg} / \mathrm{m}^{3}$ for $\mathrm{CO}_{2}$ with $3 \% \mathrm{CH}_{4}$ (IEA, 1993b).

The solubility of $\mathrm{CO}_{2}$ in water increases with pressure and decreases with temperature (Fig. 4). About 5 to $6 \mathrm{~g} \mathrm{CO}_{2}$ can be dissolved in $100 \mathrm{~g}$ fresh water under subsurface conditions. Solubility decreases, however, with salinity (Table 1); $4.5 \mathrm{~g} \mathrm{CO}_{2}$ can be dissolved in 1 molar $\mathrm{NaCl}$ solution, and $2 \mathrm{~g}$ in 2 molar $\mathrm{NaCl}$ solution. The reservoirs of the Norwegian North Sea have brines with a $\mathrm{CO}_{2}$ solubility of about $5 \mathrm{~g}$ per $100 \mathrm{~g}$ water. For the brines within the gas reservoirs in the Southern North Sea (typically a 5 molar $\mathrm{NaCl}$ solution), however, solubility may be below $1 \mathrm{~g}$ per $100 \mathrm{~g}$ water. The $\mathrm{pH}$ of the formation water will decrease as a consequence of the $\mathrm{CO}_{2}$ dissolution. (van der Meer et al., 1992; Czernichowski et al. and Lindeberg in JOULE II, 1993).

TABLE 1

$\mathrm{CO}_{2}$ solubility as function of water salinity

\begin{tabular}{c|c|c}
\hline $\begin{array}{c}\text { Water salinity } \\
\text { in NaCl percentage }\end{array}$ & $\begin{array}{c}\text { Solubility fraction } \\
\text { compared with pure water }\end{array}$ & $\begin{array}{c}\text { Standard deviation } \\
\text { due to P-T-variation }\end{array}$ \\
\hline 5 & 0.838 & 0.012 \\
\hline 10 & 0.709 & 0.020 \\
\hline 15 & 0.609 & 0.032 \\
\hline 20 & 0.525 & 0.031 \\
\hline 25 & 0.453 & 0.045 \\
\hline
\end{tabular}

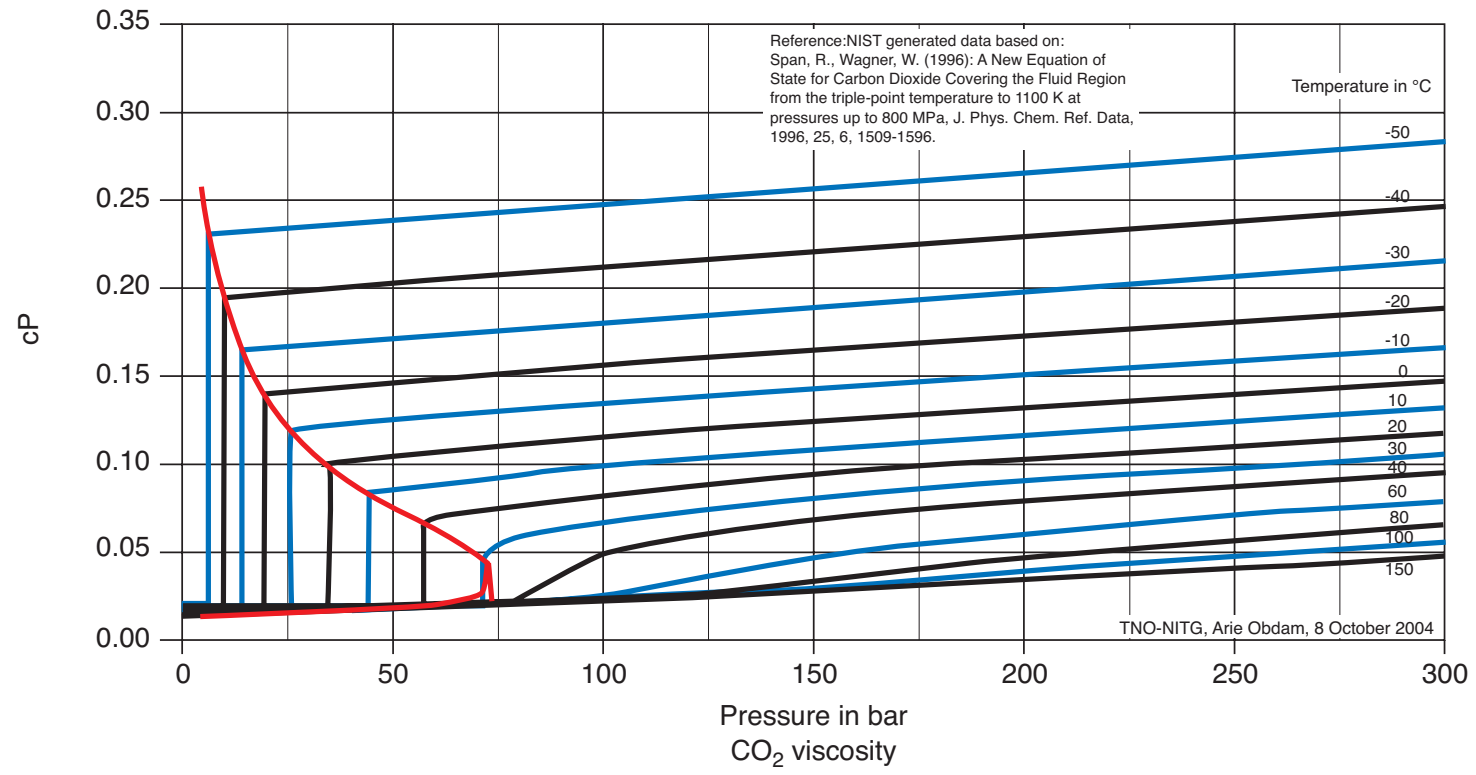

Figure 3

$\mathrm{CO}_{2}$ viscosity as function of pressure and temperature. 


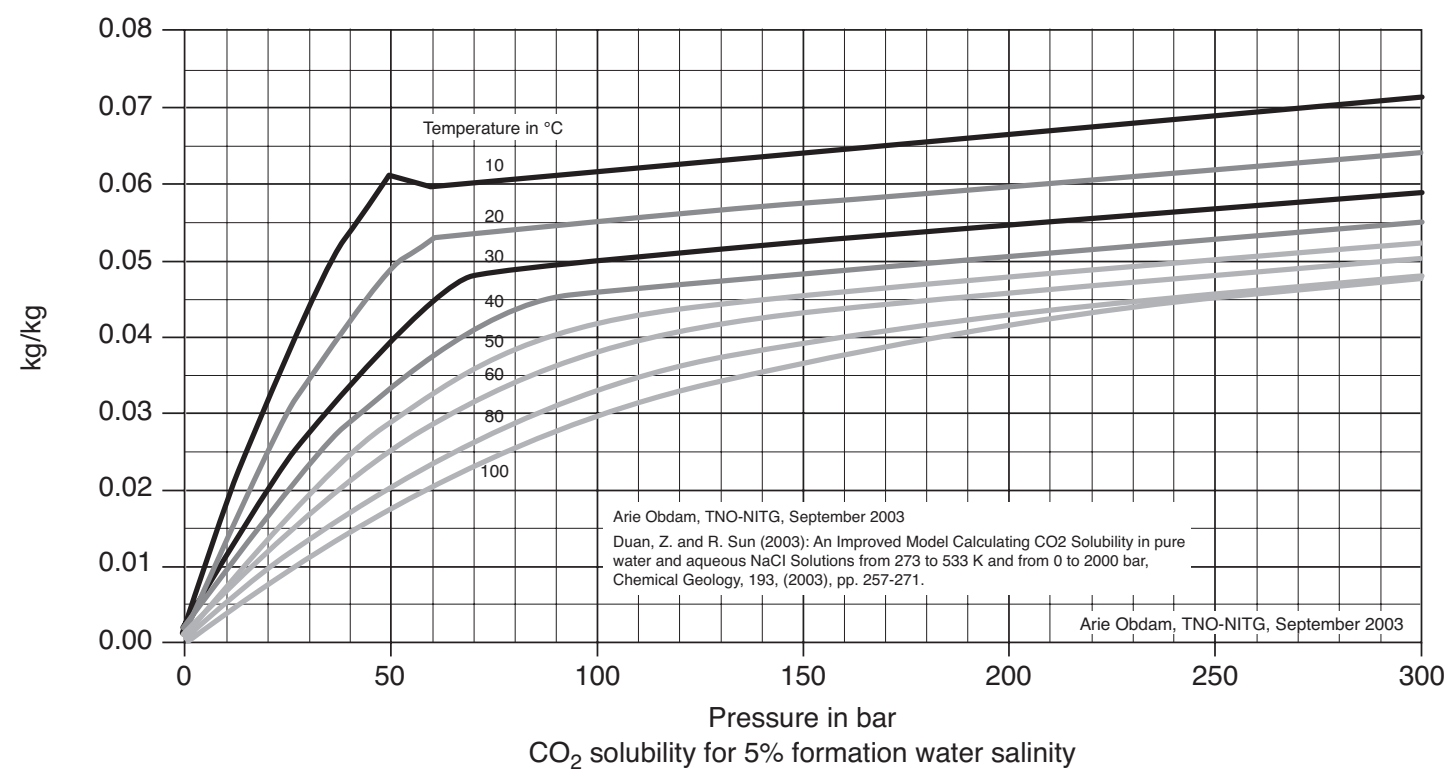

Figure 4

$\mathrm{CO}_{2}$ solubility in saline water as function of pressure and temperature.

\section{$3 \mathrm{CO}_{2}$ STORAGE IN WATER-SATURATED RESERVOIRS}

Four major mechanisms play a role in the storage of $\mathrm{CO}_{2}$ in a fully water-saturated underground reservoir or a trap on an aquifer:

- the displacement of the formation water by the injected $\mathrm{CO}_{2}$

- the dissolution of $\mathrm{CO}_{2}$ in the formation water;

- the reactivity of the minerals and the pore fluids of the reservoir rocks;

- the mixing or interaction between the original natural gas and injected $\mathrm{CO}_{2}$.

\subsection{Water Displacement by $\mathrm{CO}_{2}$}

If carbon dioxide is injected in a water-saturated reservoir at a greater pressure than the underground fluid pressure, the $\mathrm{CO}_{2}$ is able to push away the formation water. The permeability and transmissivity of the reservoir rocks, the properties of the connate water and the supercritical $\mathrm{CO}_{2}$, and whether or not the formation water is in contact with other water bodies, determines how easily the water can be displaced. The injected $\mathrm{CO}_{2}$ will show a very limited ability to displace the formation water (van der Meer et al., 1992). Because of its low underground density, the carbon dioxide floats on the formation water (gravitational segregation). In addition, because of its relatively low viscosity it moves through the intergranular pores much more quickly than the formation water. Instead of displacing the water, the $\mathrm{CO}_{2}$ partly bypasses the water and forms (multiple) viscous fingers. In most reservoirs this effect is amplified by the heterogeneity of the reservoir rock. The combined effect of the lower density and the higher mobility is that once the $\mathrm{CO}_{2}$ is injected, it immediately rises to the ceiling of the reservoir where it rapidly spreads out in viscous fingers. A computer simulation (van der Meer et al., 1992) shows that maybe only 2 to $4 \%$ of the pore volume may be filled before the $\mathrm{CO}_{2}$ spills out at the edges of the reservoir, this of course depends on the geometry of the potential storage location.

\subsection{Dissolution of $\mathrm{CO}_{2}$ in Formation Water}

The mixing of soluble fluids is brought about by molecular diffusion, and by microscopic and macroscopic dispersion. Molecular diffusion is caused by the random motion of molecules, microscopic dispersion results from the tortuous flow path through the intergranular pores, and macroscopic dispersion is determined by the flow path caused by differences in permeability. The mixing caused by molecular diffusion (dissolution) of two soluble fluids brought into contact, conforms with the Fick diffusion equation:

$$
(\mathrm{dGi}) /(\mathrm{dt})=- \text { Doi A }(\mathrm{dCi} / \mathrm{dx})
$$

Where:

$\mathrm{G}$ quantity that has diffused across the plane of the original sharp interface [moles]

$\mathrm{t}$ time [t]

Do molecular diffusion coefficient $\left[\mathrm{L}^{2} / \mathrm{t}\right]$

A cross sectional area for diffusion $\left[\mathrm{L}^{2}\right]$

C concentration [moles $/ \mathrm{L}^{3}$ ]

$\mathrm{x}$ distance [L]

Condition: no change in volume upon mixing. 
For simplicity, an average diffusion coefficient at the 50\% saturation concentration may be used. Diffusion in rocks, however, occurs along the indirect zigzag path through the intergranular pores. The diffusion coefficient has to be adjusted to account for this feature. The effective diffusion coefficient for a porous medium can be calculated from the following equation:

$$
\mathrm{D} / \mathrm{Do}=1 /(\mathrm{F} \phi)
$$

Where:

D effective molecular diffusion coefficient

Do molecular diffusion coefficient

F formation electrical resistivity factor

$\phi$ porosity.

When fluids flow through a porous medium, more mixing takes place in the direction of the flow than would be expected from molecular diffusion alone. (van der Meer $e t$ al., 1992).

Dissolution of carbon dioxide occurs at the interface of the $\mathrm{CO}_{2}$ bubble and the formation water (see Fick equation). The amount of $\mathrm{CO}_{2}$ dissolved will be proportional to the total area of the $\mathrm{CO}_{2}$-water interface. If the $\mathrm{CO}_{2}$ mobility is relatively high, the displacement of the water by the $\mathrm{CO}_{2}$ is entirely dominated by multiple viscous fingering and the area of the $\mathrm{CO}_{2}$-water interface will be large. The amount of dissolved $\mathrm{CO}_{2}$ (a function of diffusion coefficient Do) is further determined by the contaminants in the $\mathrm{CO}_{2}$, the composition of the formation water (salinity) and the possible chemical reaction between the $\mathrm{CO}_{2}$ and the reservoir minerals and the interaction between the original natural gas in the reservoir and the injected $\mathrm{CO}_{2}$.

It is expected that during the total $\mathrm{CO}_{2}$ injection activity only a small portion $(\sim 10 \%)$ of the water present would be affected by the dissolution process and this process will be dominated by local circumstances affecting the efficiency of the process.

\subsection{Reactivity of Minerals and Pore Fluid}

The chemical reaction will greatly depend on the mineralogy and texture of the rock, the composition of the formation water, the reservoir temperature and pressure, the flow rates and the timing of the reactions. Nevertheless, the following generalizations can be made (Czernichowski et al. in JOULE II, 1993):

The carbonates in carbonate rocks will dissolve, but the reaction does not significantly increase the $\mathrm{CO}_{2}$ uptake (in closed systems). In areas where the $\mathrm{CO}_{2}$ pressure is high, carbonate will dissolve and the formation water will become saturated with $\mathrm{CO}_{2}$. The carbonate may reprecipitate if the pressure falls or the temperature rises, for example in areas further from the well. Because of this local dissolution, the porosity and the permeability will increase near the injection point, but can decrease further along the flow path because of carbonate precipitation.

In sandstone reservoirs, feldspars will be leached by the dissolved $\mathrm{CO}_{2}$, followed by the precipitation of clay, carbonates and quartz. With intense leaching kaolinite will be formed. If the leaching is less intense illite, chlorite or albite precipitates. Gunter et al. (1993) came to the conclusion that sandstones containing reactive minerals can absorb more $\mathrm{CO}_{2}$ than other reservoir rocks. In the natural $\mathrm{CO}_{2}$ reservoirs of the Norphlet Formation (USA) the formation of the authigenic clays have led to a decrease in the rock permeability.

Bowker and Shuler (1991) describe the effects of $\mathrm{CO}_{2}$ flooding for enhanced recovery in reservoir rocks containing equal amounts of carbonate and feldspar (10\%). They found that the reservoir $\mathrm{pH}$ had dropped from ca. 7.5 to 3.5-4.5 since the initiation of the $\mathrm{CO}_{2}$ injection. The $\mathrm{CO}_{2}$ flood has caused a substantial increase in the concentrations of iron, calcium and magnesium in the brine produced from the dissolution of carbonate cements. Laboratory experiments showed no net change in the permeability of the reservoir rock. The increase of permeability expected with carbonate dissolution was offset by a reduction caused by the migration of clay. The experiments additionally revealed that only a fraction of the carbonate minerals were etched or dissolved by the $\mathrm{CO}_{2}$; this can be explained by a preferential flow path of the carbonated water resulting from permeability heterogeneities. Because of the pressure drop in the producing well, clogging of the well by mineral precipitation was considered a potential risk.

Attention will have to be paid on the potential reactivity of $\mathrm{CO}_{2}$ with the cap-rock materials by changing the characteristics of the water, since any geochemical reaction could alter its impervious properties. Some people even recommend selecting only the gas fields where the original gas contains $\mathrm{CO}_{2}$ for potential sequestration site.

The above text relates to the reactivity of $\mathrm{CO}_{2}$ dissolved in formation water. Little is known about the effect of supercritical $\mathrm{CO}_{2}$.

\subsection{Mixing of Gases}

The central issue in the physical processes of storing $\mathrm{CO}_{2}$ in a depleted or partly depleted gas reservoir is the extent to which native natural gas will mix with the injected $\mathrm{CO}_{2}$ and will reduce the value of the natural gas. Experimental studies have demonstrated that diffusion and dispersion processes are the same for supercritical fluids as for normal gases and liquids, (Yu et al., 1999) so there should be no unexpected penalty at supercritical conditions in this regard. Recent experimental results focused on $\mathrm{CO}_{2}$ storage in combination with enhanced gas recovery show limited mixing for $\mathrm{CH}_{4}$ displaced by $\mathrm{CO}_{2}$ in carbonate rock cores (Mamora, 2002). Inert (e.g. N2) cushion gases have been used with apparently 


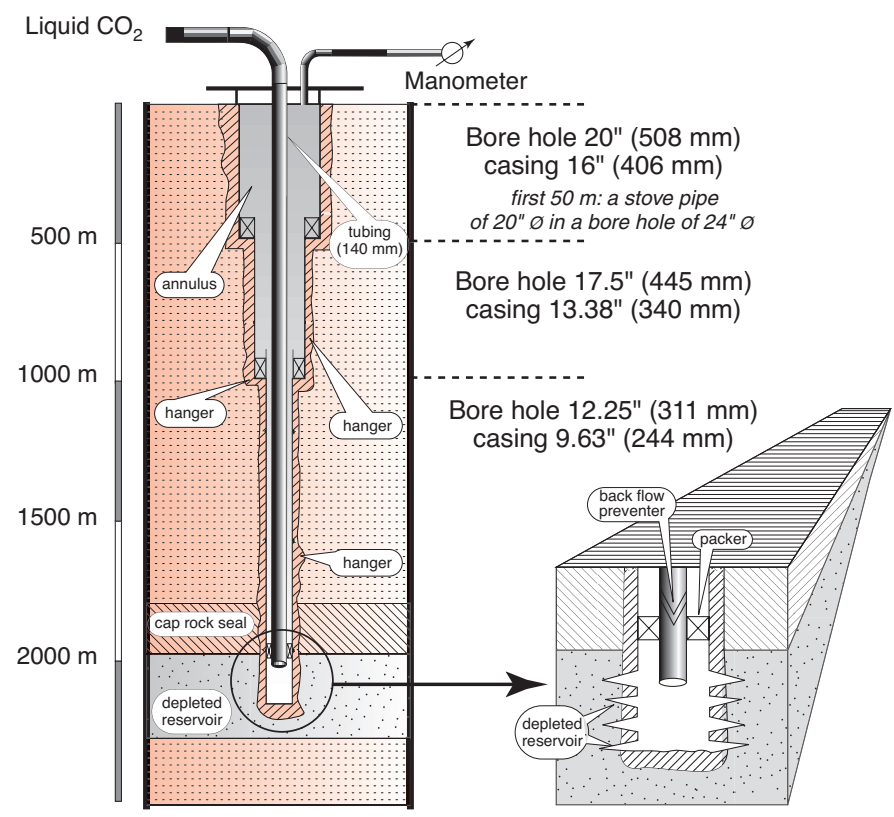

Figure 5

Sketch of the layout of a typical $\mathrm{CO}_{2}$ injection well.

acceptable degrees of mixing in France in aquifer gas storage projects for over 20 years. Furthermore, the higher density and viscosity of $\mathrm{CO}_{2}$ related to $\mathrm{CH}_{4}$ should limit mixing of the two gases especially in case of reservoirs with largely homogeneous fluid flow properties.

In simulations performed by Oldenburg (2003) with a reservoir with a relatively thin vertical dimension $(22 \mathrm{~m})$ the gas flow is predominantly horizontal. This configuration leads to gravity override and a broadening of the interfacial area between the gases and correspondingly more mixing. In gas reservoirs with a large vertical extent relative to lateral, the density effects of $\mathrm{CO}_{2}$ could be exploited by placing the $\mathrm{CO}_{2}$ deep in the reservoir and producing the natural gas from the near the top. In all, the degree to which reservoir gases mix is subject to considerable variability depending on reservoir geometry, anisotropy, heterogeneity, fracturing, and other rock or fluid properties. In, short, careful reservoir selection and activity strategy development can limit the extent of gas mixing in particular gas reservoirs, but clearly the extent and rate of gas mixing in the subsurface is uncertain and needs to be investigated further.

\section{TYPES OF RESERVOIRS AND PRODUCTION METHODS}

\subsection{Drive Mechanisms}

The mechanism of underground carbon dioxide storage in gas reservoirs can be considered as simply replacing the volume of gases and fluids produced from the reservoir by supercritical 'liquid' carbon dioxide. In other words, the pressure in the depleted reservoir, which is reduced by underground withdrawal of gas, oil and water, is restored to its initial pressure by pumping $\mathrm{CO}_{2}$ into the reservoir. According to this view, the volume of the net underground withdrawal is a measure of the capacity for $\mathrm{CO}_{2}$ storage.

A closer look at hydrocarbon reservoirs reveals, however, that this is an oversimplification. Not all reservoirs are equal in the way the gas and fluid is driven out of the subsurface. In general, the driving force is the expansion of gases and liquids in response to the pressure drop due to the net underground withdrawal, or the compaction of the reservoir due to the reduced pore pressure. Although a combination of these mechanisms may lead to the expulsion of hydrocarbons, many reservoirs have predominantly one main type of drive mechanism and all others have a negligible effect (Dake, 1978).

The type of drive mechanism plays a crucial role in the assessment of the amount of $\mathrm{CO}_{2}$ that can be stored in a reservoir, since it determines the reservoir pressure after depletion. For gas reservoirs, there are three major reservoir drive mechanisms:

- depletion drive;

- water influx drive;

- compaction drive.

Gas reservoirs differ from oil reservoirs in that they show a primary recovery efficiency in excess of $80 \%$. The gas is highly mobile, which enables it to travel easily through the 
rock, and the energy stored in the compressed gas is usually sufficient to get most of the underground gas to the surface (Giuliano, 1981).

\subsection{Depletion Drive}

The gas flows to the well because the pressure in the well is lower than the pressure in the rest of the reservoir. During the production this pressure gradient decreases. If the reservoir pressure is depleted, the production stops. Pressure will be low at the end of the production activity with possibly a low ultimate recovery factor i.e. some natural gas remaining.

\subsection{Compaction Drive}

Compaction drive is the expulsion of gas and fluids due to the dynamic reduction of the pore volume. Withdrawal of the liquid or gas reduces the fluid pressure and therefore increases the effective grain pressure, i.e. the force on the rock fabric increases because the initial support provided by the pressure of the connate fluids decreases. The increased grain pressure will provoke compaction. In other words, the reservoir is squeezed like a sponge under the burden of the overlying rocks. Unlike a sponge, the compaction of the reservoir is seldom elastic, implying that the process is irreversible. Unloading will not result in an increase in the reservoir volume.

\subsection{Water Influx Reservoirs}

A very important producing mechanism during primary gas recovery comes from water influx into the reservoir. Water is present in most sedimentary rocks. The water provides pressure to the reservoir, which aids in moving the gas to the well. In most cases the water influx will result in a near initial reservoir pressure at the end of the natural gas production activity. Additional pressure has to be found in order to store any proportional amount of $\mathrm{CO}_{2}$ in a water flooded reservoir.

\subsection{Depletion}

$\mathrm{CO}_{2}$ storage in depleted oil- or gas reservoirs is considered to be the most realistic option. This is mainly supported by the fact that these reservoirs have a proven storage capacity, plus the fact that a number of these reservoirs in the North Sea will be abandoned in the coming years. In this context we have to redefine the expression 'depleted reservoir'. Oil or gas production operations will only be stopped for economic reasons. This means that the reservoir is not depleted or empty. We have to make a distinction here between a gas reservoir and an oil reservoir. In general, the hydrocarbon recovery percentage in the case of a gas reservoir will be high, even up to $95 \%$. In the case of an oil reservoir this percentage can be very low, depending on the production mechanism. An indication of the recovery factor for different primary production mechanisms is given below (Giuliano, 1981).

In conclusion, we can say that an abandoned gas reservoir can generally be considered as depleted, and that if an abandoned oil reservoir is to be used for $\mathrm{CO}_{2}$ disposal, the initial $\mathrm{CO}_{2}$ storage activity has to be combined with an Enhanced Oil Recovery scheme. Previous work has shown that the injection of $\mathrm{CO}_{2}$ in partially depleted gas reservoir is unattractive because of the premature breakthrough of $\mathrm{CO}_{2}$ in the gas production wells (VROM, 1990). On the other hand Oldenburg (2002) has shown with simulation studies that in some instances $\mathrm{CO}_{2}$ injection in producing gas reservoirs can lead to higher gas production recovery factors. The current $\mathrm{CO}_{2}$ injection pilot in K12B reservoir, offshore The Netherlands, should soon bring some information on the final gain in reserve recovery.

\subsection{Implications for $\mathrm{CO}_{2}$ Storage}

The displacement of methane by $\mathrm{CO}_{2}$ is unconditionally stable (Mot et al., 1992). For gas reservoirs where the reservoir has not been invaded by formation water during or after production, the storage capacity is relatively easy to estimate on the basis of the produced hydrocarbons. The initial reservoir volume of the gas can be calculated from the amount of gas recovered and its expansion factor. It is assumed that this volume will be entirely available for $\mathrm{CO}_{2}$ disposal. The estimate will be conservative because some of the injected $\mathrm{CO}_{2}$ will dissolve in the formation water. Water invaded reservoirs can be considered as traps on aquifers

If the influx of natural water is the driving force, the reservoir will be filled with formation water during and after the production of hydrocarbons. The reservoir pressure will not drop significantly, because it is in equilibrium with the hydrostatic pressure of the aquifer. For water-flooded reservoirs, where the pressure has been maintained by water injection, the residual water saturation and the reservoir pressure are high. The conditions in the abandoned reservoir are probably similar to those encountered in a reservoir with natural water drive.

The conditions for $\mathrm{CO}_{2}$ storage in reservoirs with compaction drive are probably worse, because not only the initial pressure is maintained by the compaction, but the available pore volume is additionally reduced. In some unfortunate cases, the rock frame may break down and the formation water become overpressurized. Hence, for water and compaction driven expulsion, the hydrocarbon production has not created an 'empty' pore volume just waiting to be filled with $\mathrm{CO}_{2}$. The reservoirs can be regarded as a trap on an aquifer and the effective pore volume may be only a fraction of the pore volume of the produced hydrocarbons. Yet, the advantages of the reservoir over an aquifer that remain are that the 
reservoir forms a proven trap that can hold liquids for thousands to millions years, that surface and subsurface installations for hydrocarbon recovery can partly be re-used for the carbon dioxide disposal and that the reservoir properties are probably better known.

\section{CONCLUSION}

The major drawback to $\mathrm{CO}_{2}$ storage in depleted gas reservoirs is the distance between the reservoir and the $\mathrm{CO}_{2}$-producing outfit. These $\mathrm{CO}_{2}$ sources are likely to be situated in areas with a dense population. Hence, depleted reservoirs near large population centres are potential candidates for $\mathrm{CO}_{2}$ storage. Other factors that determine if a reservoir may be used for $\mathrm{CO}_{2}$ disposal are the presence of pipelines, and whether or not the reservoirs are situated in inconvenient areas, such as the deep sea, arctic realms, deserts etc. If reservoirs become depleted, some of the pipelines may be re-used for $\mathrm{CO}_{2}$ transport. In North America and Europe relatively dense networks exist for the transport of crude oil and natural gas. The total world pipeline length is about 20000 kilometers. North America possesses about 8500 and Europe 5600 kilometers of pipelines. The network is less dense in the other parts of the world. Asia-Pacific, Latin America, Africa and the Middle East have 2100, 1920, 960 and 160 kilometers of pipelines, respectively (Oil \& Gas Journal, February 8, 1993). In the Asia-Pacific area, and especially southeast Asia, east China and Japan, the energy demand and the production of gas is expected to 'boom'. Asia's growth in gas consumption will be more than double the growth in the rest of the world. This increased gas demand will need an expanded gas pipeline network

Considering the degree of depletion of the gas reservoirs, the quantity of generated power and the density of the pipeline networks, Western Europe and the USA are the most suitable candidates for $\mathrm{CO}_{2}$ disposal. The feasibility of storing $\mathrm{CO}_{2}$ in depleted gas wells was investigated for these two areas. Winter and Bergman (1993) examined the disposal potential of the depleted gas wells in the USA. They concluded that despite the large quantities of hydrocarbons extracted from reservoirs, the total underground volume available for immediate disposal is quite small, providing only enough room to store a few years power plant $\mathrm{CO}_{2}$ emissions. Texas has both the largest $\mathrm{CO}_{2}$ production and the largest storage potential. Except for Texas, transportation costs will be high, because of the large distance between the $\mathrm{CO}_{2}$ production and the disposal sites. The rather pessimistic results for the USA can be explained by the fact that they are based on volumes that are now available for $\mathrm{CO}_{2}$ disposal, instead of volumes that will become available in the future when all reserves are recovered. In addition, information on depleted reservoirs was not available for 11 hydrocarbonproducing states. If the present-day depleted reservoirs are considered, one should realize that small reservoirs with relatively little storage capacity will be over-represented, because they become exhausted rapidly. Larger reservoirs discovered years ago are still in production and will not be depleted until some unknown, possibly distant, time. As emphasized by Carmalt and St. John (1986), giant oil- and gas reservoirs contain about two-thirds of the global hydrocarbon reserves. Most of these giant reservoirs are not yet depleted, which means that by far the largest part of the storage capacity will not become available for a considerable time. The storage potential of Western Europe (EC members) has been examined by the members of the GESTCO project. For Europe, the conclusions are more optimistic. The future storage capacity of hydrocarbon reservoirs and aquifers varies from zero for Luxembourg and Portugal to more than 500 years for Norway and the United Kingdom.

\section{REFERENCES}

Bowker, K.A. and Shuler, P.J. (1991) Carbon dioxide injection and resultant alternation of the Weber Sandstone, Rangely Field, Colorado. Am. Ass. Petrol. Geol. Bull. 75, No.9, p. 1489-1499.

Carmalt, S.W. and St.John, B. (1986) Giant oil and Gas fields. In: M.T.Halbouty (Ed.), Future Petroleum Provinces of the World. Proceedings of the E. Pratt Memorial Conference, Phoenix, December 1984. Am. Ass. Petrol. Geol. Mem. 40. Tulsa, USA, 11-53.

Dake L.P. (1978) Fundamentals of reservoir engineering. Elsevier, Amsterdam, 443

Earlougher, R.C. Jr (1977) Advances in Well Test Analysis. Henry L. Doherty Memorial Fund of AIME, Society of Petroleum Engineers of AIME, New York - Dallas.

Giuliano, F.A. (Ed.) (1981) Introduction to oil and gas technology. Second edition. Intercomp Resource Development and Engineering, Inc. Houston, Texas.195.

Gunter, W.D., Perkins, E.H. and McCann, T.J. (1993) Aquifer disposal of $\mathrm{CO}_{2}$-rich gases: reaction design for added capacity. In: P.W.F. pierce (Ed.), Proceedings of the International Energy Agency carbon dioxide symposium, Oxford March 1993. Energy Convers. Mgmt, 34, No. 9-11, 941-948.

Holloway, S. and Savage, D. (1993) The potential for aquifer disposal of carbon dioxide in the UK. In: P.W.F. pierce (Ed.), Proceedings of the International Energy Agency carbon dioxide symposium, Oxford March 1993. Energy Converso Mgmt, 34, No. 9-11, 925-932.

JOULE II (1993) The underground disposal of carbon dioxide. Final Report of JOULE II Project No. CT92-0031, 232.

Katz, D.L., Cornell, D., Kobayashi, R., Poettmann, F.H., Vary, J.A., Elenbaas, J.R. and Weinaug, C.F. (1959) Handbook of Natural Gas Engineering. McGraw-Hill Book Company, New York - Toronto - London.

Kennedy, J.T. and Thodes, G. (1961) The transport properties of carbon dioxide. AIChE J., 7, 625.

Mamora D.D. and Seo J.G. (2002) Enhanced Recoveryby Carbon Dioxide Sequestration in Depleted Gas Reservoirs, Soc. Pet. Eng., SPE-77347.

Mot, E., De Baar, H.J.W., Bartelds, H., Esser, P.M., Huurdeman, A.J.M., Van de Laak, P.J.A., Michon, S.G.L. and Nielen, R.J. (1992). Confining abating $\mathrm{CO}_{2}$ from fossil fuel burning - a feasible option? (revised edition). TNO report on behalf of the Commission of the European Communities. 
Nederlandse Gasunie (1987) Nederland en z'n aardgas. N.V. Nederlandse Gasunie, 64.

Oil and Gas Journal February 8, 1993. Pipeline construction report. Gas line activity pacing growth in world pipeline construction work. p. 25-30.

Oldenburg C. (2003) Carbon Dioxide as Cushion Gas for Natural Gas Storage, Energy and Fuels, 17,240-246.

Tissot, B.P. and Welte, D.H. (1984) Petroleum Formation and Occurrence. Springer Verlag, Berlin, 699 pp.

van der Meer, L.G.H., Griffioen, J. and Gee1, C.R. (1992)

Investigations regarding the storage of carbon dioxide aquifers in the Netherlands. TNO report no. OS 92-24-A.
VROM (1990) Carbon dioxide disposal from coal based cycle power stations in depleted gasfields in The Netherlands. Ministerie van Volkhuisvesting, Ruimtelijke Ordening en Milieuhygiene.

Winter, E.M. and Bergman, P.D. (1993) Availability of Depleted Oil and Gas Reservoirs for Disposal of Carbon Dioxide in the United States. In: P.W.F. pierce (Ed.), Proceedings of the International Energy Agency carbon dioxide symposium, Oxford March 1993. Energy Convers. Mgmt, 34, No. 9-11, 1177-1187.

Yu, D., Jackson, K., and Harmon, T.C. (1999) Dispersion and Diffusion in porous Media under Supercritical Conditions. Chem. Eng. Sci., 54, 357-367.

Final manuscript received in May 2005 or distributed for profit or commercial advantage and that copies bear this notice and the full citation on the first page. Copyrights for components of this work owned by others than IFP must be honored. Abstracting with credit is permitted. To copy otherwise, to republish, to post on servers, or to redistribute to lists, requires prior specific permission and/or a fee: Request permission from Documentation, Institut français du pétrole, fax. +33147527078 , or revueogst@ifp.fr. 